\title{
Viscosity, surface tension and droplet size of sprays of different formulations of insecticides and fungicides
}

\author{
Fernando Kassis Carvalho ${ }^{\text {a, }}$, Ulisses Rocha Antuniassi ${ }^{b}$, Rodolfo Glauber Chechetto ${ }^{\text {a, b }}$, \\ Alisson Augusto Barbieri Mota a , Marcella Guerreiro de Jesus c ${ }^{c}$, Lídia Raquel de Carvalho ${ }^{\mathrm{d}}$ \\ a 689, Pinheiro Machado Street, 18.603-760 Botucatu, Sao Paulo, Brazil \\ b Sao Paulo State University, UNESP, 1780, Dr. Jose Barbosa de Barros Street, 18.610.380 Botucatu, Sao Paulo, Brazil \\ c University of Nebraska-Lincoln, 402, West State Farm Road, 69101 North Platte, NE, United States \\ d Sao Paulo State University, UNESP, Prof. Dr. Antônio Celso Wagner Zanin Street, 18618-689 Botucatu, Sao Paulo, Brazil
}

\section{A R T I C L E I N F O}

\section{Article history:}

Received 17 February 2017

Received in revised form

9 July 2017

Accepted 13 July 2017

\section{Keywords:}

Adjuvants

Application technology

Emulsifiable concentrate

Suspension concentrate

Water dispersible granules

\begin{abstract}
A B S T R A C T
The influence of three types of commercial formulation of insecticides and fungicides, emulsifiable concentrate (EC) formulation, suspension concentrate (SC) formulation and water dispersible granule (WG) formulation on the surface tension, viscosity and the droplet size spectra of sprays was evaluated using thirty commercial insecticide and fungicide products. The concentration of sprays was based on application water spray volume of $50 \mathrm{~L} \mathrm{ha}^{-1}$ using an XR 8003VS flat fan nozzle, operated at $200 \mathrm{kPa}$ pressure. The lowest surface tensions were obtained with EC formulations, while the SCs had the highest viscosities. Emulsions were the most effective at decreasing the percentage of droplets smaller than $100 \mu \mathrm{m}$ and relative span, while increasing the $\mathrm{DV}_{0.1}$ and $\mathrm{DV}_{0.5}$ values than the dispersion-type formulations, represented by WG and SC formulations. These factors should be considered for planning spray applications and reducing drift.
\end{abstract}

๑) 2017 Elsevier Ltd. All rights reserved.

\section{Introduction}

Spray drift is one of the major concerns during the application of pesticides, as it may affect the environment and human health, and the efficacy of controlling insects, fungal diseases and weeds (Newsom, 1967; De Schampheleire et al., 2008; Hilz and Vermeer, 2013).

Fungicides and insecticides are commonly sprayed using similar spray qualities in Brazil. Because of the need for good coverage and penetration in the canopy, most applications are done using smaller droplets (usually from very fine to medium spray quality), most frequently using standard flat fan nozzles. Dual flat fan and hollow cone nozzles are also used to spray these pesticides, but because of the higher risk of spray drift (Chechetto et al., 2014; Carvalho et al., 2017) the adoption of these nozzles is decreasing.

Pesticide formulations affect parameters such as viscosity,

\footnotetext{
* Corresponding author.

E-mail addresses: fernando@agroefetiva.com.br (F.K. Carvalho), ulisses@fca. unesp.br (U.R. Antuniassi), rodolfo@agroefetiva.com.br (R.G. Chechetto), alisson@ agroefetiva.com.br (A.A.B. Mota), marcellaguerreiro@hotmail.com (M.G. de Jesus), lidiarc@ibb.unesp.br (L.R. de Carvalho).
}

surface tension and droplet size, which influence the drift potential of sprays atomized with conventional flat fan nozzles (Miller and Butler Ellis, 2000).

The presence of emulsion droplets present in sprays using EC formulations, or the small particles in SC or WG formulations, affect the liquid sheet formed at the nozzle, influencing the droplet spectra, and consequently, the drift potential (Miller and Butler Ellis, 2000; Hilz and Vermeer, 2013). According to these authors, emulsions or dispersions may lead to formation of larger droplets than those formed when spraying water-soluble formulations.

Nevertheless, most spray application research is conducted using "blank" formulations, often water, where there are no active ingredients, or using just adjuvants, trying to simulate the characteristics of commercial products. This is done to avoids contamination of the laboratory, or exposure of people to pesticide residues. This is also due in part to the prohibitions of usage of active ingredients by law in some locations (Hoffmann et al., 2007; Nuyttens et al., 2009; Fritz et al., 2010). Some researchers also have evaluated commercial formulations, but for comparing different formulations of the same active ingredient (Sanderson et al., 1997; Kirk, 2000).

It is not clear, however, how commercial formulations of 
pesticides affect surface tension, viscosity and droplet size spectra of sprays. For instance, there is no consensus whether the impact of EC, WG, and SC formulations on droplet size is the same for insecticides and fungicides. This represents an important area of study for improving spray applications quality, as well as for mitigating spray drift.

Thus, the aim of this study was to evaluate the effects of EC, SC and WG formulations of insecticide and fungicide products, represented by five commercial products for surface tension, viscosity and droplet size spectra of spray.

\section{Material and methods}

Five samples of commercial products comprising EC, SC and WG formulations of insecticides and fungicides were selected for evaluation in a 2 (insecticide versus fungicide) $x 3$ (EC versus SC versus WG) factorial design, in a completely randomized experiment. This selection of products was based on their availability in the Brazilian market.

The concentration of the pesticide in water was determined according to the label recommendations, prioritizing those for controlling Asian soybean rust (Phakopsora pachyrhizi Sydow \& P. Sydow), to fungicides, and velvetbean caterpillar (Anticarsia gemmatalis Hübner), to insecticides, both for the use in soybeans (Glycine $\max \left(\mathrm{L}\right.$.) Merril) with application volumes of $50 \mathrm{~L} \mathrm{ha}^{-1}$. This volume application rate is commonly used in some regions of Brazil for ground applications (Chechetto et al., 2014; Carvalho et al., 2017).

A flat fan nozzle XR 8003VS (TeeJet, Spraying Systems, Wheaton, Illinois, USA) was used at an operating pressure of $200 \mathrm{kPa}$ (2 bar), according to earlier trials by Moreira Júnior and Antuniassi (2010), and to represent the nozzle type commonly used for fungicides and insecticides applications in Brazil (Chechetto et al., 2014). Environmental condition during these studies were $20.5^{\circ} \mathrm{C}\left( \pm 0.74^{\circ} \mathrm{C}\right)$ and relative humidity of $73.51 \%( \pm 3.47 \%)$.

The droplet spectra were measured with a VisiSizer P15 equipment (Oxford Lasers, Imaging Division, Oxford, U.K.), Particle/ Droplet Image Analyses (PDIA), according to the methodology described by Guler et al. (2007). This method for measuring droplets, ranging from $21 \mu \mathrm{m}$ up to $3490 \mu \mathrm{m}$ is detailed by Kashdan et al. (2003). $\mathrm{A} \mathrm{CO}_{2}$ propellant was used to pressurize the spray system.

Among the available options offered by the equipment used to characterize droplet size spectra, $\mathrm{DV}_{0.1}, \mathrm{DV}_{0.5}$ (or Volume Median Diameter, VMD) and $\mathrm{DV}_{0.9}$ (the diameter of droplets representing $10 \%, 50 \%$ and $90 \%$ of the sprayed volume), $\%<100 \mu \mathrm{m}$ (percentage by volume composed of droplets smaller than $100 \mu \mathrm{m}$ ) and relative span (difference in diameter for $\mathrm{DV}_{0.9}$ and $\mathrm{DV}_{0.1}$ of the sprayed volume divided by the $\mathrm{DV}_{0.5}$ ) were selected (Mugele and Evans, 1951; Tate and Janssen, 1966; Goering and Smith, 1978; Hewitt, 2007; Ferguson et al., 2015; Al Heidary et al., 2014).

Relative span is a dimensionless parameter used to indicate uniformity of the droplet size spectra, where smaller values indicate a narrower spectrum (Hewitt, 2007). The $\%<100 \mu \mathrm{m}$ has a positive correlation with spray drift potential, while $\mathrm{DV}_{0.5}$ has a negative correlation (Courshee, 1959; Miller, 1998; Antuniassi et al., 2011; Oliveira et al., 2015). Droplet spectra data was replicated three times.

A Brookfield DV-II + Pro viscometer measured solution viscosity (Oliveira et al., 2015). The instrument was equipped with a cylinder of $100 \mathrm{~mm}$ external diameter (spindle \# S-00) at 60-rpm rotation, according to the manufacturer's recommendations. The surface tension of the solutions was determined using the drop-weight method (Gans and Harkins, 1930; Saad et al., 2011; Oliveira et al., 2015). This method uses the weight of droplets generated at the end of a capillarity tip to indicate the surface tension. Five replications were used to characterize both parameters.

All the evaluations were completed using two spray solutions for the same treatment, to ensure that analytical mistakes during the evaluations were minimized. The treatments are described in Tables 1 and 2 .

The data was subjected to analyses of variance (ANOVA) and, when significant differences were observed, the average of the results were compared by the Tukey's test at $5 \%$ level of significance using SAS (SAS, Cary, NC, USA) software.

\section{Results and discussion}

There was no interaction between formulations and pesticides $(P>0.05)$. Furthermore, there were no statistical differences between the classes of pesticides, but there were between the types of formulations for all the evaluated parameters (Table 3). However, the results for relative Span, $\mathrm{DV}_{0.1}, \mathrm{DV}_{0.5}$, and $\%<100 \mu \mathrm{m}$ were similar between fungicides and insecticides for each evaluated formulation. This shows that the type of formulation was the determinant factor for the results obtained for those parameters.

The SC and WG formulations resulted in the relative span being about $34 \%$ and $47 \%$, respectively, higher than for EC formulations, that was close to 1.2 . The $\%<100 \mu \mathrm{m}$ was also higher for those formulations, by approximately $120 \%$ and $250 \%$, respectively, than that observed for EC formulations, which resulted in $\%<100 \mu \mathrm{m}$ smaller than $6 \%$.

The viscosity of SC formulations was higher than observed with EC and WG. According to Knowles (2008), Paul and Robeson (2008) and Zhang et al. (2011) this is explained by the components, usually polymers, used to keep the solid active ingredient particles in suspension in SC formulations, increasing the viscosity of spray liquid. According to the authors, these substances also have the capability of altering parameters as such as $\mathrm{DV}_{0.5}$ and $\%<100 \mu \mathrm{m}$. However, as observed in this study, the effects of emulsions on increasing $\mathrm{DV}_{0.1}, \mathrm{DV}_{0.5}$ and decreasing $\%<100 \mu \mathrm{m}$ has exceeded the effect of higher viscosity of SC formulations.

The SC and WG formulations resulted in $\mathrm{DV}_{0.5}$ approximately $20 \%$ and $34 \%$, smaller than observed to EC formulations, respectively. Hilz and Vermeer (2012) observed that an oil dispersion formulation (OD) of an imidacloprid insecticide had a $\mathrm{DV}_{0.5}$ around $20 \%$ higher than that obtained for WG and SC formulations of that insecticide. These authors used an XR 11003VS nozzle, at $300 \mathrm{kPa}$, simulating a volume rate of $200 \mathrm{~L} \mathrm{ha}^{-1}$ to conduct that research. The $\%<100 \mu \mathrm{m}$ for the OD formulation was about $50 \%$ smaller than the observed to the other evaluated formulations. These data are in congruence with the observed in the present study.

When liquids being atomized are forced through the orifice of flat fan nozzles, a sheet is formed that spreads out as it breaks up with perforations forming within the sheet that forms ligaments at its edge and then as individual droplets that create the spray. As some droplets are formed there is often a smaller satellite droplet also formed (Matthews et al., 2014a).

Hewitt et al. (2002) explained that droplet spectra is affected principally by the physical characteristics of spray liquids, and do not depend on active ingredients. The presence, particularly the proportion of the spray liquid in droplets smaller than $100 \mu \mathrm{m}$, including the very small satellite droplets determines the drift potential. However, the nature of some active ingredients may determine the formulation type, thus whether it is soluble in a suitable solvent or is a solid more suited to a particulate formulation. And thus indirectly affects physical characteristics of the spray liquids (Matthews et al., 2014b).

The EC formulations had the lowest surface tension results, about $37 \mathrm{mN} \mathrm{m}^{-1}$, while for the other treatments it ranged from $44.42 \mathrm{mN} \mathrm{m}^{-1}$, for SC fungicides, to $63.43 \mathrm{mN} \mathrm{m}^{-1}$, for $\mathrm{WG}$ 
Table 1

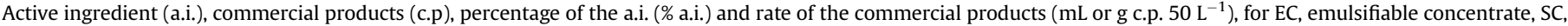
suspension concentrate, and WG, water dispersible granules, formulations of insecticides.

\begin{tabular}{|c|c|c|c|}
\hline Active ingredient & Commercial product & $\%$ a.i. & $\begin{array}{l}\text { Rate } \\
\text { (mL or g c.p. } 50 \mathrm{~L}^{-1} \text { ) }\end{array}$ \\
\hline \multicolumn{4}{|l|}{ Insecticides } \\
\hline \multicolumn{4}{|l|}{ EC } \\
\hline $\begin{array}{l}\text { chlorpyrifos } \\
\text { deltamethrin } \\
\text { prophenophos + lufenuron } \\
\text { abamectin } \\
\text { bifenthrin }\end{array}$ & $\begin{array}{l}\text { Lorsban }^{(\mathbb{R}} 480 \mathrm{BR} \\
\text { Decis }^{\circledR} 25 \mathrm{EC} \\
\text { Curyon }^{\circledR} 550 \mathrm{EC} \\
\text { Vertimec }^{\circledR} 18 \mathrm{EC} \\
\text { Talstar }^{\circledR} 100 \mathrm{EC}\end{array}$ & $\begin{array}{l}48 \\
2.5 \\
50+5 \\
1.8 \\
10\end{array}$ & $\begin{array}{l}1000 \\
300 \\
150 \\
600 \\
160\end{array}$ \\
\hline \multicolumn{4}{|l|}{ SC } \\
\hline $\begin{array}{l}\text { thiamethoxam + lambda-cyhalothrin } \\
\text { flubendiamide } \\
\text { methoxyfenozide } \\
\text { imidacloprid + beta-cyfluthrin } \\
\text { teflubenzuron }\end{array}$ & $\begin{array}{l}\text { Engeo }{ }^{\mathrm{TM}} \text { Pleno } \\
\text { Belt }^{\circledR} \\
\left.\text { Intrepid }^{(}\right) 240 \text { SC } \\
\text { Connect }^{(\mathbb{R}} \\
\text { Nomolt }^{(8)} 150\end{array}$ & $\begin{array}{l}14.1+10.6 \\
48 \\
24 \\
10+1.25 \\
15\end{array}$ & $\begin{array}{l}200 \\
70 \\
150 \\
1000 \\
50\end{array}$ \\
\hline \multicolumn{4}{|l|}{ WG } \\
\hline $\begin{array}{l}\text { fipronil } \\
\text { thiamethoxan } \\
\text { imidacloprid } \\
\text { thiodicarb } \\
\text { imidacloprid }\end{array}$ & $\begin{array}{l}\text { Fipronil } 800 \text { WG } \\
\text { Actara }^{\circledR} 250 \text { WG } \\
\text { Evidence }^{\circledR} 700 \text { WG } \\
\text { Larvin }^{\circledR} \text { WG } \\
\text { Imidagold } 700 \text { WG }\end{array}$ & $\begin{array}{l}80 \\
25 \\
70 \\
80 \\
70\end{array}$ & $\begin{array}{l}40 \\
200 \\
250 \\
70 \\
250\end{array}$ \\
\hline
\end{tabular}

Table 2

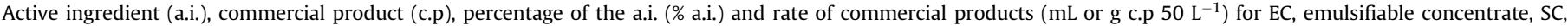
suspension concentrate, and WG, water dispersible granules, formulations of fungicides.

\begin{tabular}{|c|c|c|c|}
\hline Active ingredient & Commercial product & $\%$ a.i. & $\begin{array}{l}\text { Rate } \\
\text { (mL or g c.p. } 50 \mathrm{~L}^{-1} \text { ) }\end{array}$ \\
\hline \multicolumn{4}{|l|}{ Fungicides } \\
\hline \multicolumn{4}{|l|}{ EC } \\
\hline $\begin{array}{l}\text { tebuconazole } \\
\text { tebuconazole } \\
\text { pyraclostrobin } \\
\text { difenoconazole } \\
\text { difenoconazole }\end{array}$ & $\begin{array}{l}\left.\text { Folicur }^{(}\right) 200 \mathrm{EC} \\
\text { Orius }^{\circledR} 250 \mathrm{EC} \\
\text { Comet }^{\circledR} \\
\text { Score }^{\circledR} 200 \\
\text { Tilt }^{(}\end{array}$ & $\begin{array}{l}21.3 \\
25 \\
25 \\
25 \\
25\end{array}$ & $\begin{array}{l}500 \\
400 \\
300 \\
200 \\
400\end{array}$ \\
\hline \multicolumn{4}{|l|}{ SC } \\
\hline $\begin{array}{l}\text { difenoconazole }+ \text { difenoconazole } \\
\text { trifloxystrobin }+ \text { prothioconazole } \\
\text { azoxystrobin }+ \text { cyproconazole } \\
\text { trifloxystrobin }+ \text { tebuconazole } \\
\text { fluxapyroxad + pyraclostrobin }\end{array}$ & $\begin{array}{l}\text { Aproach }{ }^{\circledR} \text { Prima } \\
\text { Fox }^{\circledR} \\
\text { Priori Xtra }^{\circledR} \\
\text { Nativo }^{\circledR} \\
\text { Orkestra }^{\circledR}\end{array}$ & $\begin{array}{l}20+8 \\
15+17.5 \\
20+8 \\
10+20 \\
16.7+33.3\end{array}$ & $\begin{array}{l}300 \\
400 \\
300 \\
500 \\
350\end{array}$ \\
\hline \multicolumn{4}{|l|}{ WG } \\
\hline $\begin{array}{l}\text { azoxystrobin } \\
\text { azoxystrobin }+ \text { benzovindiflupir } \\
\text { mancozeb } \\
\text { mancozeb } \\
\text { metiran }\end{array}$ & $\begin{array}{l}\text { Amistar WG } \\
\text { Elatus }^{\mathrm{TM}} \\
\text { Manzate }^{\circledR} \text { WG } \\
\text { Unizeb }^{\circledR} \text { Gold } \\
\text { Polyran }^{\circledR} \text { DF }\end{array}$ & $\begin{array}{l}50 \\
30+15 \\
75 \\
75 \\
70\end{array}$ & $\begin{array}{l}120 \\
300 \\
3000 \\
3200 \\
3000\end{array}$ \\
\hline
\end{tabular}

insecticides. According to Miller and Butler Ellis (2000) the presence of surfactants in formulations will affect surface tension, but it is not the unique parameter affecting droplet size.

Knowledge of the droplet spectrum, especially the proportion by volume of the smallest droplets, often regarded as those below $100 \mu \mathrm{m}$ for different formulations and adjuvants, if used, is important for different nozzles and operating pressures to be able to choose most suitable nozzle to minimize spray drift (Hilz and Vermeer, 2013; Gandolfo et al., 2014).

The tests recorded here refer to one specific flat fan nozzle and provide data relevant to current practice in Brazil and countries where similar practices are used. However, with greater concern about downwind spray drift, Nuyttens et al. (2007) compared several different nozzles and confirmed that low-drift flat-fan nozzles and air-inclusion nozzles applied significantly less volume in the smallest droplets liable to drift. Further study is needed to see if these nozzles should be used in Brazil, especially as they vary in design and in some cases, produce a very coarse spray with high VMD, that is less likely to provide adequate coverage with some pesticides to achieve adequate control of some pests, when using low volume application rates.

In conclusion, this study provides data of the droplet spectra and properties of certain pesticide formulations, relevant to current practices in Brazil. Such data is important for planning spray applications and to adopt drift reduction technologies (DRTs).

At the low volume application rate considered (50 $\mathrm{L} \mathrm{ha}^{-1}$ ) and use of one nozzle (XR 8003VS) and operating pressure (200 kPa), the emulsifiable concentrate formulations of both insecticides and 
Table 3

Means of the evaluated parameters for spray solutions composed by fungicides and insecticides of EC, SC and WG formulations.

\begin{tabular}{|c|c|c|c|}
\hline \multirow[t]{2}{*}{ Class } & \multicolumn{3}{|c|}{ Evaluated parameters $^{\mathrm{a}}$} \\
\hline & $\overline{\mathrm{EC}^{\mathrm{b}}}$ & SC & WG \\
\hline \multicolumn{4}{|c|}{$\mathrm{ST}\left(\mathrm{mN} \mathrm{m}^{-1}\right)$} \\
\hline Insecticide & $39.23 c A^{c}$ & $61.53 \mathrm{bA}$ & $63.43 a A$ \\
\hline Fungicide & $35.73 c \mathrm{~A}$ & $44.42 \mathrm{bB}$ & $51.29 \mathrm{aB}$ \\
\hline \multicolumn{4}{|c|}{ Viscosity (mPa s) } \\
\hline Insecticide & $1.15 \mathrm{bB}$ & $1.27 \mathrm{aA}$ & $1.10 \mathrm{cB}$ \\
\hline Fungicide & $1.12 \mathrm{cA}$ & 1.19aB & $1.17 \mathrm{bA}$ \\
\hline \multicolumn{4}{|l|}{ Span } \\
\hline Insecticide & $1.25 \mathrm{cA}$ & $1.59 \mathrm{bA}$ & $1.77 \mathrm{aA}$ \\
\hline Fungicide & $1.16 \mathrm{cA}$ & $1.63 \mathrm{bA}$ & $1.76 \mathrm{aA}$ \\
\hline \multicolumn{4}{|l|}{$\mathrm{DV}_{0.1}(\mu \mathrm{m})$} \\
\hline Insecticide & $124.41 \mathrm{aA}$ & $102.83 \mathrm{bA}$ & $90.01 \mathrm{cA}$ \\
\hline Fungicide & $126.13 a A$ & $101.17 \mathrm{bA}$ & $91.73 \mathrm{cA}$ \\
\hline \multicolumn{4}{|c|}{$\mathrm{DV}_{0.5}$ or $\mathrm{VMD}(\mu \mathrm{m})$} \\
\hline Insecticide & $255.20 \mathrm{aA}$ & $200.95 \mathrm{bA}$ & $\overline{165.10 \mathrm{cA}}$ \\
\hline Fungicide & $247.41 \mathrm{aA}$ & $200.21 \mathrm{bA}$ & $166.68 \mathrm{cA}$ \\
\hline \multicolumn{4}{|l|}{$\mathrm{DV}_{0.9}(\mu \mathrm{m})$} \\
\hline Insecticide & $440.78 \mathrm{aA}$ & $415.80 \mathrm{bA}$ & $382.50 \mathrm{cA}$ \\
\hline Fungicide & $412.58 \mathrm{bB}$ & $424.51 \mathrm{aA}$ & $383.23 \mathrm{cA}$ \\
\hline \multicolumn{4}{|c|}{$\%<100 \mu \mathrm{m}(\%)$} \\
\hline Insecticide & $5.91 \mathrm{cA}$ & $11.37 \mathrm{bA}$ & $18.05 \mathrm{aA}$ \\
\hline Fungicide & $4.73 \mathrm{cA}$ & $12.08 \mathrm{bA}$ & $16.81 \mathrm{aA}$ \\
\hline
\end{tabular}

${ }^{a}$ ST: surface tension; Span: relative Span; $\mathrm{DV}_{0.1}, \mathrm{DV}_{0.5}$ and $\mathrm{DV}_{0.9}(10 \%, 50 \%$ and $90 \%$ of the sprayed volume contains droplets smaller than a droplet whose diameter is the $\mathrm{DV}_{0.1}, \mathrm{DV}_{0.5}$ or $\mathrm{DV}_{0.9}$, respectively), \%<100 $\mu \mathrm{m}$ (percentage by volume composed by droplets smaller than $100 \mu \mathrm{m}$ ).

b EC: Emulsifiable concentrate; SC: concentrate suspension; WG: water dispersible granules.

c Different lowercase letters on the lines, and capital letters on the columns, statistically differ according to the Tukey's test $(\alpha=0.05)$.

fungicides increased the volume median diameter of the spray with less spray prone to drift compared with the SC and WG formulations.

Small differences detected in surface tension and viscosity of the three types of formulation were not reflected in the overall droplet size data.

\section{Acknowledgements}

The authors would like to thanks Dr. Graham A. Matthews for had provided information, knowledge and for his help revising the text, and the team of the Pesticide Application Technology Laboratory of the University of Sao Paulo, UNESP/Botucatu, for their assistance with the analysis. We also would like to thank Bayer, Dow AgroSciences, Syngenta and UPL for their donations of some pesticides used for this research. This work was supported by the National Council for Scientific and Technological Development (99999.003632/2015-06).

\section{References}

Al Heidary, M., Douzals, J.P., Sinfort, C., Vallet, A., 2014. Influence of spray characteristics on potential spray drift of field crop sprayers: a literature review. Crop Prot. 63, 120-130. http://dx.doi.org/10.1016/j.cropro (Accessed 6 May 2014).

Antuniassi, U.R., Velini, E.D., Oliveira, R.B., Oliveira, M.A.P., Figueiredo, Z.N., 2011. Systems of aerial spraying for soybean rust control. Eng. Agrícola 31, 695-703. http://dx.doi.org/10.1590/S0100-69162011000400008 (Accessed 2 December 2016).

Carvalho, F.K., Antuniassi, U.R., Chechetto, R.G., Mota, A.A.B., 2017. Characteristics and challenges of pesticide spray applications in Mato Grosso, Brazil. Outlooks Pest Manag. 28, 4-6. https://doi.org/10.1564/v28_feb_02 (Accessed 11 May 2017).

Chechetto, R.G., Mota, A.A.B., Antuniassi, U.R., Carvalho, F.K., Vilela, C.M. Silva, A.C.A., 2014. Caracterização da taxa de aplicação e pontas de pulverização utilizadas no estado de Mato Grosso. Magistra 26, 89-97. file://C:/Users/ Fernando/Downloads/113-12 3 Nota Cientifica.pdf (Accessed 6 July 2016).

Courshee, R.J., 1959. Drift spraying for vegetation baiting. Bull. Entomol. Res. 50, 355-369. http://dx.doi.org/10.1017/S0007485300054626.

De Schampheleire, M., Baetens, K., Nuyttens, D., Spanoghe, P., 2008. Spray drift measurements to evaluate the Belgian drift mitigation measures in field crops. Crop Prot. 27, 577-589. http://dx.doi.org/10.1016/j.cropro (Accessed 7 August 2016).

Ferguson, J.C., O'Donnell, C.C., Chauhan, B.S., Adkins, S.W., Kruger, G.R., Wang, R., Urach Ferreira, P.H., Hewitt, A.J., 2015. Determining the uniformity and consistency of droplet size across spray drift reducing nozzles in a wind tunnel. Crop Prot. 76, 1-6. https://doi.org/10.1016/j.cropro.2015.06.008 (Accessed 9 May 2017).

Fritz, B., Hoffmann, W., Bagley, W., 2010. Effects of spray mixtures on droplet size under aerial application conditions and implications on drift. Appl. Eng. Agric. 26, 21-29. https://elibrary.asabe.org/abstract.asp? aid $=29467 \& t=2 \&$ redir $=\&$ redirType $=$; (Accessed 10 May 2015).

Gans, D., Harkins, W., 1930. The drop weight method for the determination of surface tension. The effect of an inclination of the tip upon the drop weight. J. Am. Chem. Soc. 52, 2287-2289. http://pubs.acs.org/doi/abs/10.1021/ ja01369a014 (Accessed 15 May 2017).

Gandolfo, M.A., Carvalho, F.K., Chechetto, R.G., Gandolfo, U.D., Moraes, E.D., 2014 Effect of working pressure at different spray nozzles on drift quantification in wind tunnel. Eng. Agric. 34, 66-73. http://www.scielo.br/scielo.php? script=sci_arttext\&pid=S0100-69162014000100008 (Accessed 9 July 2015).

Goering, C.E., Smith, D.B., 1978. Equations for droplet size distributions in sprays Trans. ASAE 21, 209-216. Saint Joseph. https://elibrary.asabe.org/abstract.asp? aid $=35277 \& \mathrm{t}=2 \&$ redir $=\&$ redirType $=($ Accessed 5 February 2016).

Guler, H., Zhu, H., Ozkan, H., 2007. Spray characteristics and drift reduction potential with air induction and conventional flat-fan nozzles. Trans. ASABE 50, 745-754. https://elibrary.asabe.org/abstract.asp?aid=23129\&t=2\&redir=\&redirType $=$ (Accessed 17 October 2016).

Hewitt, A.J., Johnson, D.R., Fish, J.D., Hermansky, C.G., Valcore, D.L., 2002. Development of the spray drift task force database for aerial applications. Environ. Toxicol. Chem. 21, 648-658. http://dx.doi.org/10.1002/etc.5620210326 (Accessed 7 June 2016).

Hewitt, A.J., 2007. Spray optimization through application and liquid physical property variables-I. Environmentalist 28, 25-30. http://dx.doi.org/10.1007/ s10669-007-9044-5 (Accessed 8 September 2015).

Hilz, E., Vermeer, A.W.P., 2012. Effect of formulation on spray drift: a case study for commercial imidacloprid products (Org.). In: Anderson, P.G., et al. (Eds.), Aspects of Applied Biology: International Advances in Pesticides Application, vol 144. Association of Applied Biologists, Wellesbourn, pp. 445-452.

Hilz, E., Vermeer, A.W.P., 2013. Spray drift review: the extent to which a formulation can contribute to spray drift reduction. Crop Prot. 44, 75-83. http://dx.doi.org/ 10.1016/j.cropro (Accessed 20 October 2012).

Hoffmann, W.C., Walker, T.W., Smith, V.L., Martin, D.E., Fritz, B.K., 2007. Droplet-size characterization of handheld atomization equipment typically used in vector control. J. Am. Mosq. Control Assoc. 23, 315-320. https://www.ncbi.nlm.nih. gov/pubmed/17939513 (Accessed 15 September 2015).

Kashdan, J.T., Shrimpton, J.S., Whybrew, A., 2003. Two-phase flow characterization by automated digital image analysis. Part 1: fundamental principles and calibration of the technique. Part. Part. Syst. Charact. 20, 387-397. http:// dx.doi.org/10.1002/ppsc.200300897.

Kirk, I.W., 2000. Aerial spray drift from different formulations of glyphosate. Trans. ASAE 43, 555-559. http://dx.doi.org/10.13031/2013.2735. https://elibrary. asabe.org/abstract.asp? aid $=2735 \& \mathrm{t}=2 \&$ redir $=\&$ redirType $=($ Accessed 9 April 2015).

Knowles, A., 2008. Recent developments of safer formulations of agrochemicals Environ 28, 35-44. http://link.springer.com/article/10.1007/s10669-007-90454 (Accessed 4 June 2016).

Matthews, G.A., Bateman, R., Miller, P., 2014a. Hydraulic nozzles. In: Pesticide Application Methods, 4ed. John Wiley \& Sons, Ltd, Oxford, pp. 125-157.

Matthews, G.A., Bateman, R., Miller, P., 2014b. Formulation of pesticides. In: Pesticide Application Methods, 4ed. John Wiley \& Sons, Ltd, Oxford, pp. 63-89.

Miller, P.C.H., 1998. The measurement and prediction of spray drift - work at the Silsoe Research Institute. In: Bucley, D. (Ed.), PROCEEDINGS of the NORTH AMERICAN CONFERENCE On PESTICIDE SPRAY DRIFT MANAGEMENT, pp. 229-244. Portland, Maine.

Miller, P.C.H., Butler Ellis, M.C., 2000. Effects of formulation on spray nozzle performance for applications from ground-based boom sprayers. Crop Prot. 19 609-615. http://dx.doi.org/10.1016/S0261-2194(00)00080-6 (Accessed12 August 2015).

Moreira Júnior, O., Antuniassi, U.R., 2010. Construção e validação de um túnel de vento para ensaios de estimativa da deriva em pulverizações agrícolas. Energ. Agric. 25, 118-136. http://revistas.fca.unesp.br/index.php/energia/article/view/ 71/52 (Accessed 9 October 2015).

Mugele, R.A., Evans, H.D., 1951. Droplet size distribution in sprays. Ind. Eng. Chem. 43, 1317-1324. http://pubs.acs.org/doi/abs/10.1021/ie50498a023 (Accessed 14 April 2015). 
Newsom, L.D., 1967. Consequences of insecticide use on non-target organisms. Annu. Rev. Entomology, La. 12, 257-286. http://www.annualreviews.org/doi/ pdf/10.1146/annurev.en.12.010167.001353 (Accessed 22 October 2015).

Nuyttens, D., Baetens, K., De Schampheleire, M., Sonck, B., 2007. Effect of nozzle type, size and pressure on spray droplet characteristics. Biosyst. Eng. 97, 333-345. http://dx.doi.org/10.1016/j.biosystemseng (Accessed 1 August 2015).

Nuyttens, D., Taylor, W.A., De Schampheleire, M., Verboven, P., Dekeyser, D., 2009 Influence of nozzle type and size on drift potential by means of different wind tunnel evaluation methods. Biosyst. Eng. 103, 271-280. http://dx.doi.org 10.1016/j.biosystemseng (Accessed 20 August 2015)

Oliveira, R.B., Antuniassi, U.R., Gandolfo, M.A., 2015. Spray adjuvant characteristics affecting agricultural spraying drift. Eng. Agric. 35, 109-116. http://www.scielo. br/scielo.php?script=sci_arttext\&pid=S0100-69162015000100109 (Accessed 5 November 2015)

Paul, D.R., Robeson, L.M., 2008. Polymer nanotechnology: nanocomposites. Polym. Guildf. 49, 3187-3204. http://www.sciencedirect.com/science/article/pii/
S0032386108003157 (Accessed 17 March 2016).

Saad, S.M.I Policova, Z Neumann, 2011. Design and accuracy of pendant drop methods for surface tension measurement. Colloids Surfaces A Physicochem. Eng. Aspects 384, 448-452.

Sanderson, R., Hewitt, A.J., Huddleston, E.W., Ross, J.B., 1997. Relative drift potential and droplet size spectra of aerially applied Propanil formulations. Crop Prot. 16 , 717-721 http://www.sciencedirect.com/science/article/pii/ S0261219497000641 (Accessed 10 September 2015).

Tate, R.W., Janssen, L.F., 1966. Droplet size data for agricultural spray nozzles. Transaction ASAE 9 (3), 303-308. http://elibrary.asabe.org/abstract.asp? $\mathrm{aid}=39960 \& \mathrm{t}=2 \&$ redir=\&redirType $=$ (Accessed 8 June 2016).

Zhang, W., Qu, X., Jon, D., Patel, J., Narayanan, K.S., 2011. Application of new solid polymeric dispersant, Easy-Sperse ${ }^{\mathbb{R}}$ P-20 (spray-dried polymer composites) in suspension concentrates and water dispersible granule formulations improvement in compensability and rain-fastness. J. ASTM Int. 7, 89-99. https://www.astm.org/DIGITAL_LIBRARY/STP/PAGES/STP152720120007.htm. 